\title{
Analysis of transferability of microsatellite primers (SSR) in wild Passiflora species and intraspecific genetic diversity in Passiflora alata
}

\author{
M.A.A. Silva ${ }^{1}$, M.M. Souza ${ }^{1}$, G.S. Silva ${ }^{1}$, C.A.F. Melo ${ }^{1}$, R.X. Corrêa ${ }^{1}$, \\ I.S. Araújo ${ }^{2}$ and L.D.H.C.S. Conceição ${ }^{3}$ \\ ${ }^{1}$ Departamento de Ciências Biológicas, Universidade Estadual de Santa Cruz, \\ Ilhéus, BA, Brasil \\ ${ }^{2}$ Departamento de Ciências Vegetais, \\ Universidade Federal Rural do Semi-Árido, Mossoró, RN, Brasil \\ ${ }^{3}$ Embrapa Cerrados, Planaltina, Brasília, DF, Brasil
}

Corresponding author: M.M. Souza

E-mail: souzamagg@yahoo.com.br

Genet. Mol. Res. 13 (3): 5908-5918 (2014)

Received May 17, 2013

Accepted November 27, 2013

Published August 7, 2014

DOI http://dx.doi.org/10.4238/2014.August.7.6

\begin{abstract}
The genus Passiflora L. is the most representative of Passifloraceae, with over 500 known species, among which 150-200 originated from Brazil. In addition to the great commercial importance of this genus for the fruit market, many of the species have exotic flowers with a huge diversity of colors and can thereby be exploited as ornamental plants. This study was aimed at investigating the transferability of microsatellite primers in wild Passiflora species (P. cacao, P. cincinnata, P. glandulosa, $P$. gibertii, and $P$. mucronata) and characterizing $29 P$. alata accessions using microsatellite primers that were previously developed in a library enriched with microsatellites from $P$. edulis f. flavicarpa for $P$. alata. The interspecies cross-amplification rate varied, and $P$. cacao exhibited the highest rate of amplification, suggesting a greater degree of proximity to $P$. edulis. The study of intraspecific accessions in $P$. alata found genetic similarity, with values ranging from 0.47 to 1.00 and an average similarity
\end{abstract}


of 0.74 . Hence, this study revealed the intraspecific genetic variability of $P$. alata in the Universidade Estadual de Santa Cruz's Active Germplasm Bank and will lead to the adoption of mating strategies between accessions; thus making their use more suitable for breeding purposes.

Key words: Genetic diversity; Passion flowers; Microsatellite markers; Transferability of primers

\section{INTRODUCTION}

Passiflora is the most represented genus in the Passifloraceae family, with a broad geographical distribution and species occurring both in tropical and warm temperate regions (Cervi, 2006). Despite the large representation of Passiflora, this genus encompasses about 520 species (Cervi, 2005); yet, many of the species are still being discovered and characterized (Vitta and Bernacci, 2004; Bernacci and Souza, 2012). The representatives of the genus Passiflora are distributed in tropical forests stretching from North America to South America, with endemic species of the Brazilian flora. The economic importance of passion flowers stems chiefly from its fruit. $P$. alata (sweet passion fruit) and $P$. edulis f. flavicarpa (passion fruit) are the most commercialized species, which are generally directed at the food industry. Other qualities are assigned to species of this genus, such as medicinal use - where $P$. incarnata stands out because of its anxiolytic and cosmetic effect (Dhawan et al., 2004). P. caerulea, P. incarnata, and several interspecific hybrids cultivated mainly in Europe and the USA stand out in the ornamental market (Rushing, 2003). The variables determining the potential for the ornamental market are shape, size, color, and beauty; this goes as much for floral pieces as it does for vegetative parts (Abreu et al., 2009). Despite Passiflora being little recognized as ornamental plants in Brazil (Abreu et al., 2009), many studies aimed at obtaining cultivars directed at the soils and climate of Brazil are in progress (Abreu, 2008; Santos et al., 2008; Viana, 2009).

The characterization of cultivars and wild species maintained in germplasm banks cover the morphoagronomic (Souza et al., 2008), cytogenetic (Peñaloza and Pozzobon, 2007), botanic (Guen et al., 2002), and molecular markers (Crochemore et al., 2003). Among the molecular markers, the simple sequence repeat (SSR) and SSR-polymerase chain reaction (PCR) microsatellites are widely used in studies of inter- and intra-specific diversity and population inferences and thus help to outline conservation strategies (Pádua, 2004). Among the advantages of SSR markers, one may mention the codominant nature of the observed polymorphism, as well as the multiallelism and high polymorphism information content (Ferreira and Grattapaglia, 1996). On the other hand, the biggest technical bottleneck of SSR-PCR is the necessity of prior knowledge of microsatellite sequences to design specific primers for SSR loci. Nevertheless, the potential transferability of primers between species of the same genus has been reported in several plant groups, allowing the application of the SSR-PCR technique in other species (Ferreira and Grattapaglia, 1996; Oliveira et al., 2005).

Studies involving the molecular approach with microsatellite markers can be considered incipient because of the scarcity of these markers for species of the genus Passiflora. SSR markers are only available for three species of the genus: $P$. edulis f. flavicarpa, $P$. alata (Pádua et al., 2005; Oliveira, 2006), and $P$. cincinnata (Cerqueira-Silva et al., 2012). Using 25 microsatellite primers developed for $P$. edulis f. flavicarpa, cross-amplification has provided different transfer rates (Cerqueira-Silva et al., 2008a; Conceição et al., 2009). 
This study aimed to assess the rate of transferability of SSR primers from five wild species kept at the Active Germplasm Bank of Universidade Estadual de Santa Cruz (UESC). At the same time, the genetic diversity among accessions of $P$. alata was analyzed for future use in conservation and breeding programs.

\section{MATERIAL AND METHODS}

The analysis of transferability of SSR primers involved five wild species of the genus Passiflora: P. cacao, P. cincinnata, P. gibertii, P. glandulosa, and P. mucronata (Table 1). The germplasm used in this study was obtained from samples collected in fragments of the Atlantic Forest from southern Bahia, and accessions granted by research institutions of Brazil. All of the species were identified and deposited at the Agronomic Institute of Campinas, São Paulo, and Universidade Federal do Paraná, Curitiba, Paraná. During analysis, the species were kept in the Active Germplasm-Passifloras of UESC, Ilhéus, BA, Brazil $\left(39^{\circ} 10^{\prime} \mathrm{W}, 14^{\circ} 39^{\prime} \mathrm{S}\right.$, altitude $78 \mathrm{~m}$ ), in a rustic greenhouse measuring $6 \times 7 \times 39 \mathrm{~m}$ (the semi-arc type), covered with plastic plus additives against ultraviolet rays, and coated with $30 \%$ shade cloth.

\begin{tabular}{|c|c|c|c|}
\hline Species & Accession number & Origin & Acquisition \\
\hline P. alata Curtis & $101,102,104,242,244,245,317,53$ & No information & Donation \\
\hline P. alata & $54,55,78,79,80,81,82,83,86,88,109,114,115$ & Camacan, Serra Bonita, BA & Collection \\
\hline P. alata & $25,39,312$ & Instituto Plantarum & Donation \\
\hline P. alata & $59,60,85,87,359$ & Fazenda Ouro Verde, Una, BA & Collection \\
\hline P. cacao Bernacci and Souza & $344,346,347,348$ & Serra Bonita, Camacan, BA & Collection \\
\hline P. cincinnata Mast. & 199 & No information & Donation \\
\hline P. cincinnata & 42,52 & Pato de Minas, MG & Donation \\
\hline P. cincinnata & 334 & Fazenda Ouro Verde, Una, BA & Collection \\
\hline P. gibertii N.E. Brown & $171,172,173,174$ & Embrapa Cerrados & Donation \\
\hline P. glandulosa Cav. & G02, G03, G04, G05, G06, G07 & Fazenda Ouro Verde, Una, BA & Collection \\
\hline P. mucronata Lam. & $127,128,129,130$ & Praia do Aeroporto, Ilhéus, BA & Collection \\
\hline
\end{tabular}

Genomic DNA was extracted in duplicate from young leaves using the methodology proposed by Doyle and Doyle (1990). SSR amplifications were performed using 31 microsatellite primer pairs, where 10 primers, pe01, pe02, pe03, pe04, pe05, pe06, pe07, pe08, pe09, and pe10 (Oliveira et al., 2005), and 14 primers, pe11, pe27, pe28, pe37, pe38, pe42, pe54, pe 58, pe 59, pe60, pe64, pe66, pe75, and pe 90 (Oliveira, 2006), were previously developed for P. edulis f. flavicarpa. The primers A01BP3, A01FP3, A03AP3, A06FP1, A07FP1, A08GP1, and A08FP1 were developed for P. alata (Pádua et al., 2005). The SSR-PCR amplifications were performed according to Oliveira et al. (2005), Oliveira (2006), and Pádua et al. (2005).

The tests assessing transference from primers of $P$. alata and $P$. edulis f. flavicarpa to different species were made in four accessions of each species as a means to amplify specific loci and adjust the reaction conditions. The amplification products were subjected to gel electrophoresis on $2.5 \%$ agarose gels and $6 \%$ denaturing polyacrylamide gels and were then detected by staining with silver nitrate $\left(\mathrm{AgNO}_{3}\right)$ according to Creste et al. (2001).

The same primers used in the analysis of transferability were used in the analysis of intraspecific genetic diversity in P. alata, as represented by 29 accessions (Table 1). The products generated by the amplification of microsatellite primers were considered to be domi- 
nant markers, and the presence and absence of SSR loci were evaluated. The amplified bands specific to SSR loci were analyzed and used in the construction of a binary matrix wherein 1 (one) was the value denoting the presence of the band while 0 (zero) denoted absence. Binary data served as the basis for calculating the similarity matrix for all accessions using Dice's similarity coefficient (Dice, 1945). Analyses were performed using unweighted pair group method with an arithmetic mean (UPGMA) and the sequential agglomerative hierarquic nonoverlapping procedure. Likewise, a principal coordinate analysis (PCO) generated using Dice's similarity coefficient was conducted. In order to estimate the significance of the correlation between the similarity matrix and the grouping matrix, the test of matrix comparison of Mantel (1967) was applied with a thousand permutations and observed from the cophenetic correlation (r). All analyses were performed using the NTSYSpc 2.0 software (Rohlf, 2000).

\section{RESULTS}

\section{Transferability rate of microsatellite primers in wild Passiflora species}

Pairs of specific primers for SSR loci were previously developed for two economically important species of the genus Passiflora: P. edulis Sims f. flavicarpa (24 primers) (Oliveira et al., 2005; Oliveira, 2006) and P. alata (7 primers) (Pádua et al., 2005). These 31 primers were tested in five wild Passiflora species to verify the transferability percentage of SSR primers from the respective species. The results revealed that a minimum of 7 and a maximum of 18 SSR primers were transferred per species (Tables 2 and 3). Among the 7 primers that were previously developed for $P$. alata, the highest rate of amplification was observed in $P$. cacao and $P$. gibertii (28.5\%). On the other hand, no amplification was observed in the species $P$. glandulosa and $P$. mucronata. The transferability of the 24 primers developed for $P$. edulis f. flavicarpa revealed a higher amplification percentage $(62.5 \%)$ in $P$. cacao. The remaining species, in turn, had a lower percentage of transferability (37.5\%), with the exception of $P$. glandulosa, whose transfer rate was lower (29.1\%) (Table 3).

For each primer pair that was used in the transferability tests, the percentage of amplification of all of the five species studied was obtained (Table 4). The amplification rate of primers remained between 14.2 and $42.8 \%$, with null amplification in some of the primers. The primer pairs pe07 and pe 75 showed a high percentage of transferability $(87.7 \%)$. The primers A07FP1 and A08FP1 exhibited transferability rates of 71.4 and $57.1 \%$, respectively.

Table 2. Cross-amplification results reported in the 31 loci analyzed for the five wild Passiflora species on $2.5 \%$
agarose gel.
\begin{tabular}{lccccc}
\hline Primers & P. cacao & P. cincinnata & P. gibertii & P. glandulosa & P. mucronata \\
\hline A01BP3 & - & - & - & - & - \\
A01FP3 & - & - & - & - & - \\
A03AP3 & - & - & - & - & - \\
A06FP1 & + & + & + & - & - \\
A07FP1 & - & - & - & - & - \\
A08GP1 & + & - & 28.5 & - & - \\
A08FP1 & 28.5 & 14.4 & T $(\%)$
\end{tabular}

$\mathrm{T}(\%)=$ transferability rate; $(-)=$ no amplification; $(+)=$ observed amplification. Primers developed for $P$. alata (Pádua et al., 2005). 


\begin{tabular}{|c|c|c|c|c|c|}
\hline Primers & P. cacao & P. cincinnata & P. gibertii & P. glandulosa & P. mисronata \\
\hline pe01 & + & + & - & + & - \\
\hline pe02 & + & - & - & + & - \\
\hline pe03 & - & - & - & - & - \\
\hline pe04 & + & - & - & - & + \\
\hline pe05 & - & - & - & - & + \\
\hline pe06 & + & - & - & + & + \\
\hline pe07 & + & + & - & + & + \\
\hline pe08 & - & + & - & - & - \\
\hline pe09 & - & - & + & - & - \\
\hline pe10 & + & - & - & - & - \\
\hline pe11 & + & - & - & - & + \\
\hline pe27 & - & + & - & - & - \\
\hline pe28 & - & - & - & + & - \\
\hline pe37 & + & - & + & - & + \\
\hline pe38 & + & - & + & + & - \\
\hline pe 42 & + & - & - & - & - \\
\hline pe54 & + & - & + & - & + \\
\hline pe58 & + & - & + & + & + \\
\hline pe59 & + & - & - & - & - \\
\hline pe60 & - & - & - & - & - \\
\hline pe64 & - & + & - & - & - \\
\hline pe66 & + & - & - & - & + \\
\hline pe75 & + & + & + & - & + \\
\hline pe90 & + & - & + & - & - \\
\hline $\mathrm{T}(\%)$ & 62.5 & 37.5 & 37.5 & 29.1 & 37.5 \\
\hline
\end{tabular}

$\mathrm{T}(\%)=$ transferability rate; $(-)=$ no amplification; $(+)=$ observed amplification. Primers developed for $P$. edulis $\mathrm{f}$. flavicarpa (Oliveira et al., 2005; Oliveira, 2006).

Table 4. Transferability rates observed in the presence of PCR products on agarose gel with primer pairs designed from Passiflora edulis f. flavicarpa and P. alata in wild Passiflora species.

\begin{tabular}{lc}
\hline Primers & $\mathrm{T}(\%)$ \\
\hline pe07, pe75 & 87.7 \\
A07FP1 & 71.4 \\
A08FP1, pe37, pe58 & 57.1 \\
pe01, pe02, pe04, pe06, pe11, pe27, pe54, pe66 & 42.8 \\
pe08, pe38, pe59, pe64 & 28.5 \\
A06FP1, A08GP1, pe03, pe10, pe28, pe42, pe90, pe05 & 14.2 \\
A01BP3, A01FP3, A03AP3 & 0.0 \\
\hline
\end{tabular}

$\mathrm{T}(\%)=$ transferability rate.

\section{Analysis of intraspecific genetic diversity in accessions of $P$. alata}

The intraspecific study analyzing accessions of $P$. alata was carried out with the use of six microsatellite primer pairs, revealing a total of 18 polymorphic alleles. The average similarity obtained was 0.74 , whereas the observed maximum similarity was 1.00 and the minimum was 0.47 . The correlation coefficient ( $\mathrm{r}$ ) of 0.78 suggests a good fit between the graphical representations of distances generated by the UPGMA grouping method. The cophenetic distance was high by the Mantel test $(\mathrm{p}[\mathrm{Zrdmd} \leq \mathrm{Zobs}]=1000 / t$-test $=10,2716)$, since values $\geq 0.56$ are considered to be optimal (Vaz Patto et al., 2004). The lowest similarity coefficient of SSR loci (0.47) was observed between the accessions 39 and 59 and between 27 and 109. On the other hand, the highest similarity coefficient (1.00) was observed between genotypes 102 and 244, 53 and 312, 54 and 55-82-87, and 55 and 82-87 (Table 5), showing an overall genetic similarity among SSR loci. 


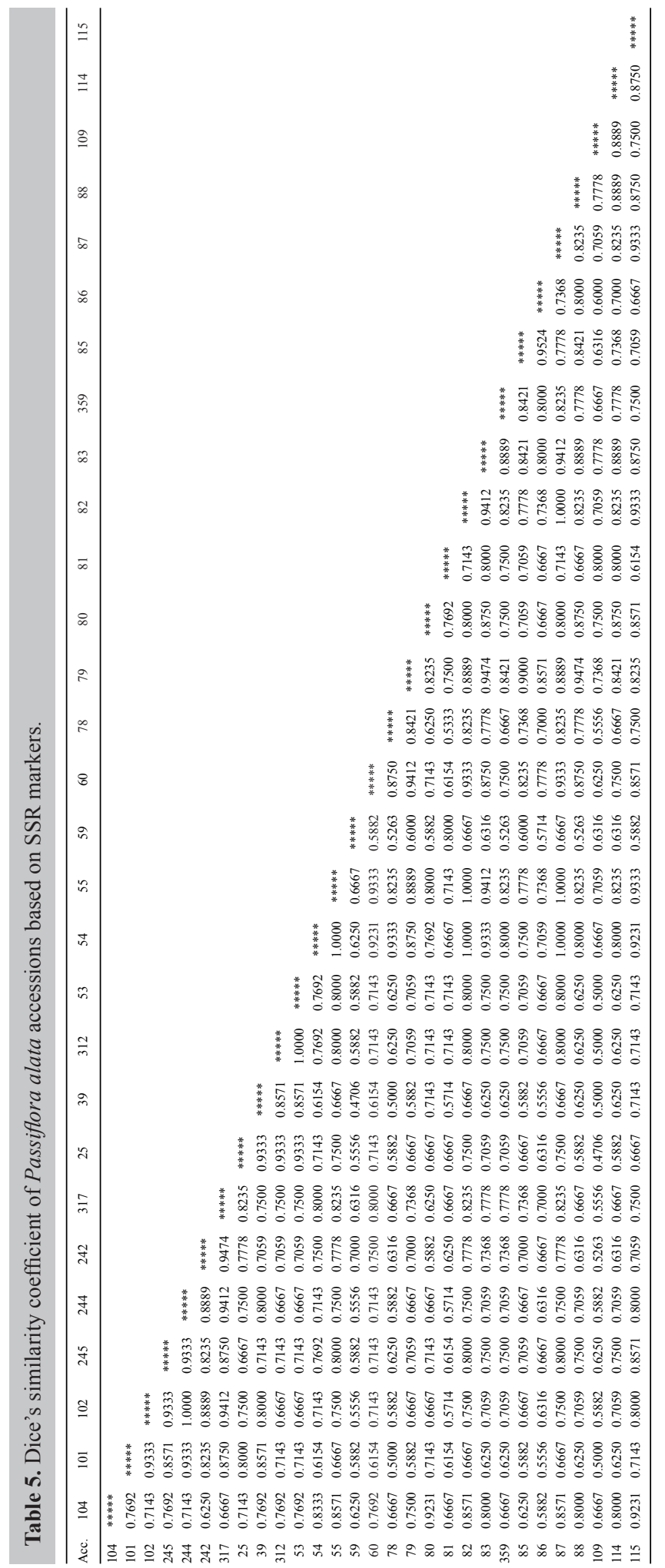


A graphical representation of the group of individuals clearly formed three groups that were obtained from the cut-off point calculated by the average similarity $=0.74$ (Figure 1) (Silva et al., 2008; Amorim et al., 2009). Group I was formed by 17 accessions and includes most of the accessions collected in Camacan and Una, BA. Group II, in turn, consists of 10 accessions and exhibited individuals whose genotype data are identical for the loci analyzed: accessions 102 and 244, and 312 and 53. Individuals from this group are the ones whose places of collection have not been reported, and all accessions were granted by Instituto Plantarum. Group III only consisted of two accessions. This group significantly differed from the other groups (Figure 1). In some of the groups, no relationship was observed between the place or origin of collection and genetic similarity. This fact was observed in group III, which consisted of two accessions of different origins and whose similarity values were low when compared with those of groups I and II (Figure 1).

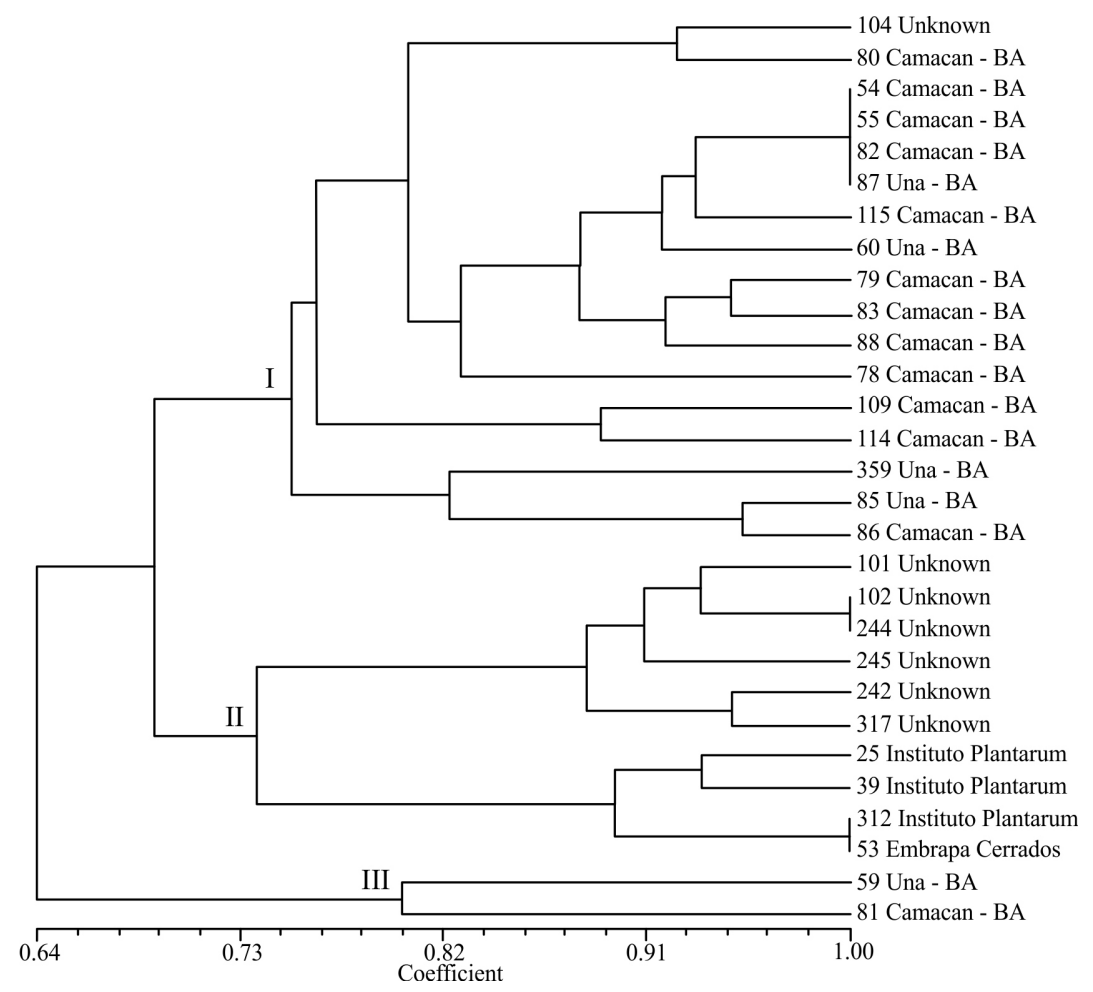

Figure 1. Dendrogram resulting from the grouping analysis of the 29 Passiflora alata genotypes, obtained by UPGMA using the Dice's similarity coefficient. The cophenetic correlation coefficient is 0.84 .

Besides the statistical grouping by UPGMA, a PCO analysis was carried out using Dice's similarity coefficient. PCO analysis showed that the distribution of accessions of $P$. alata was similar to that observed in the dendrogram generated by UPGMA. Three distinct groups were formed on the axes $\mathrm{C} 1$ and $\mathrm{C} 2$. Furthermore, various other accessions from $P$. alata, such as 59, 80, 81, 109, and 245, have an isolated distribution (Figure 2). 


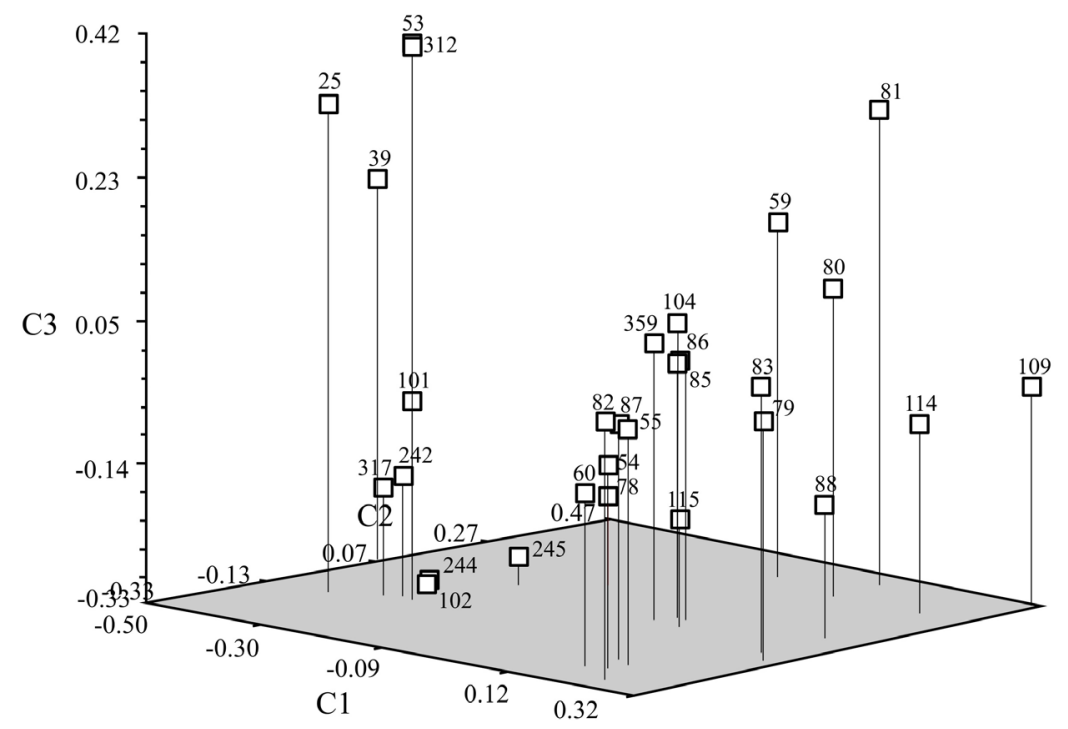

Figure 2. Analysis of principal coordinates generated using the Dice's similarity coefficient.

\section{DISCUSSION}

Previous studies addressing the transferability of SSR primers in species of the genus Passiflora have been reported in the literature (Pádua, 2004; Cerqueira-Silva et al., 2008a; Conceição et al., 2009). The transferability analysis of SSR primers that were designed from the library enriched with microsatellites of $P$. alata and $P$. pohlii was carried out in 80 wild Passiflora species and showed a higher transfer (78.75\%) for the primer A08FP1 that was developed for $P$. alata (Pádua, 2004). In this study, the primer pair A08FP1 exhibited a high transferability rate $(71.4 \%)$. The transferability rate of 25 primer pairs developed for $P$. edulis f. flavicarpa (Oliveira et al., 2005; Oliveira, 2006) in wild Passiflora species (P. cincinnata, $P$. coccinea, $P$. kermesina, $P$. gardneri, $P$. rubra, $P$. capsulares, $P$. misera, $P$. suberosa, $P$. nitida, P. watsoniana, P. bahienses, P. eichleriana, and P. setacea) were between 32 and $76 \%$; in addition, nine of the 13 species showed amplification exceeding 52\% (Cerqueira-Silva et al., 2008a). Using the same primers, similar results were obtained for other Passiflora species ( $P$. foetida var. foetida, P. galbana, P. amethystina, and $P$. sublanceolata), indicating a transfer rate of 40-44\% (Conceição et al., 2009). The observed cross-amplification in P. gardneri, $P$. edulis f. flavicarpa, $P$. watsoniana, and $P$. bahiensis using seven pairs of primers developed for $P$. alata (Pádua et al., 2005) showed different amplification rates among the species, in the order of $86,86,57$, and $29 \%$, respectively (Cerqueira-Silva et al., 2008b).

The transferability rates presented in this study were satisfactory in most of the species used and primer pairs. Hence, results demonstrate that the transferability of SSR loci from $P$. alata and P. edulis to wild Passiflora species was successful because there was amplification in all of the species analyzed. Nevertheless, different transferability rates were observed. The successful transfer of SSR primer pairs between species depends upon the coexistence of the 
annealing site of SSR primers. With a view to save time, financial, and human resources for the development of SSR markers for Passiflora, transferability is seen as a promising technique for the genomic analysis of species of this genus.

In the analysis of amplifications with primers obtained from a library enriched with microsatellites of $P$. edulis f. flavicarpa, $P$. cacao was the species with the highest amplification rate. This event can be attributed to some morphological similarities and the genetic proximity between $P$. cacao and $P$. edulis (Viana, 2009) because they exhibit high crossability rates. Other studies associated the rate of amplification with the taxonomic affinity of some species (Primmer et al., 2005; Wang et al., 2005; Barbará et al., 2007). Instances of successful use of heterologous primers were obtained from species of the family Meliaceae, which were subjected to amplification tests using primers specific for Swietenia humilis Zucc. Similar to the Passiflora species observed in this study, the highest percentage of amplification occurred in species of the genus Swietenia (White and Powell, 1997).

Despite the high transfer rate of some primers, it has been noted that primers A01BP3, A01FP3, and A03AP3 (developed for P. alata) did not amplify products in any of the species studied. The lack of conservation of primer annealing sites may have prevented the amplification of microsatellite loci, namely null alleles (Garner, 2002), and this condition is mostly observed in the event of primer transfer between different species, which usually affects all individuals to the same degree. In the germplasm of Triticum dicoccon Schrank, it was noted that 10 of the 29 SSR primers that were used resulted in null alleles (Teklu et al., 2007).

The analysis of results obtained from the intraspecific variation of $P$. alata showed a high cophenetic value $(\mathrm{r}=0.84)$, denoting good agreement with the values of genetic distance. The dendrogram generated by UPGMA distributed most of the accessions into two major groups (I and II). The analyses of similarity coefficient, grouping via UPGMA, and PCO analysis showed that some accessions of $P$. alata can indicate duplicate genotypes. Accessions 312 and 53 were granted by different institutions, but they showed the same genotype, and the places of their collections were unknown. Therefore, one may assume that these accessions are from the same place or that there may have been an exchange of germplasm between the two institutions. In assessing the diversity of some genotypes of Theobroma cacao with the use of microsatellite primers, redundant accessions were found because of the presence of hybrids from the same cross (sibling seeds). This result improved the representation of the collection (Irish et al., 2010).

The groupings made by UPGMA and PCO confirmed that the polymorphism observed by SSR loci amplification in accessions of $P$. alata was sufficient to distribute the accessions of this species. In Vaccinium spp (blueberry), only three pairs of microsatellite primers were sufficient to form groupings consistent with the reality of the collection (Silva et al., 2008). The results obtained in this study suggest that the accessions of $P$. alata can be useful for cross-breeding purposes because they are genetically distant in relation to the SSR loci analyzed, particularly between accessions from the groups I (80 and 104) and III (59 and 81). Likewise, the greatest genetic distance between accessions from groups I and II can be used to select genotypes that are aimed at the genetic improvement of $P$. alata. The identification of redundant accessions with high genetic similarity prevents crosses between genotypes with high similarity at the SSR loci; this fact would allow for the narrowing of the genetic basis of progenies obtained via intraspecific crossing. 


\section{ACKNOWLEDGMENTS}

The authors thank Conselho Nacional de Desenvolvimento Científico e Tecnológico $(\mathrm{CNPq})$ for the scholarship to M.A.A. Silva and Fundação de Amparo à Pesquisa do Estado da Bahia (FAPESB) and Universidade Estadual de Santa Cruz (UESC) for financial support. We also thank the student Alexandre Nunes Garcia for laboratory technical support.

\section{REFERENCES}

Abreu PP (2008). Análises em Passiflora palmeri, Passiflora foetida e Híbridos F1 Ornamentais: Relações Citogenéticas e Caracterização Fisiológica. Master’s thesis, Produção Vegetal, Universidade Estadual de Santa Cruz, Ilhéus.

Abreu PP, Souza MM, Santos EA and Pires MV (2009). Passion flower hybrids and their use in the ornamental plant market: perspectives for sustainable development with emphasis on Brazil. Euphytica 166: 307-315.

Amorim EP, Lessa LS, Ledo CAS and Amorim VBO (2009). Caracterização agronômica e molecular de genótipos diplóides melhorados de bananeira. Rev. Bras. Frutic. 31: 154-161.

Barbará T, Palma-Silva C, Paggi GM, Bered F, et al. (2007). Cross-species transfer of nuclear microsatellite markers: potential and limitations. Mol. Ecol. 16: 3759-3767.

Bernacci LC and Souza MM (2012). Passiflora cacao (Passifloraceae), a new species from southern Bahia, Brazil. Novon 22: 1-7.

Cerqueira-Silva CBM, Conceição LDHCS, Cardoso-Silva CB and Oliveira AC (2008a). Amplificação Cruzada de Marcadores Microssatélites (SSR) em Espécies do Gênero Passiflora. 20th Congresso Brasileiro de Fruticultura, 54th Annual Meeting of the Interamerican Society for Tropical Horticulture, Vitória.

Cerqueira-Silva CBM, Conceição LDHCS, Cardoso-Silva CB and Oliveira AC (2008b). Amplificação Cruzada de Marcadores Microssatélites (SSR) entre Espécies de Maracujazeiro (Passifloraceae; Passiflora). 54th Congresso Brasileiro de Genética, Salvador.

Cerqueira-Silva CB, Santos ES, Souza AM, Mori GM, et al. (2012). Development and characterization of microsatellite markers for the wild South American Passiflora cincinnata (Passifloraceae). Am. J. Bot. 99: e170-e172.

Cervi AC (2005). Espécies de Passiflora L. (Passifloraceae) publicadas e descritas nos últimos 55 anos (1950-2005) na América do Sul e principais publicações brasileiras. Estudos Biol. 27: 19-24.

Cervi AC (2006). O gênero Passiflora L. (Passifloraceae) no Brasil, espécies descritas após o ano de 1950. Adumbr. Summae Ed. 16: 1-5.

Conceição LDHCS, Souza MM, Silva MM and Belo GO (2009). Cross-amplification of microsatellites and variation among species of Passiflora. Simpósio Brasileiro de Genética e Biologia Molecular de Planta, Búzios.

Creste S, Neto AT and Figueira A (2001). Detection of single sequence repeat polymorphisms in denaturing polyacrylamide sequencing gels by silver staining. Plant Mol. Biol. Rep. 19: 299-306.

Crochemore ML, Molinari HBC and Vieira LGE (2003). Genetic diversity in passion fruit (Passiflora spp.) evaluated by RAPD markers. Braz. Arch. Biol. Technol. 46: 521-527.

Dhawan K, Dhawan S and Sharma A (2004). Passiflora: a review update. J. Ethnopharmacol. 94: 1-23.

Dice LR (1945). Measures of the amount of ecologic association between species. Ecology 26: 297-302.

Doyle JJ and Doyle JL (1990). Isolation of plant DNA from fresh tissue. Focus 12: 13-15.

Ferreira ME and Grattapaglia D (1996). Introdução ao uso de marcadores genéticos em análise genética. 2nd edn. Embrapa, Cenargen, Brasília.

Garner TW (2002). Genome size and microsatellites: the effect of nuclear size on amplification potential. Genome 45: 212-215.

Guen VL, Garcia D, Mattos CRR and Clément-Demange A (2002). Evaluation of field resistance to Microcyclus ulei of a collection of Amazonian rubber tree (Hevea brasiliensis) germplasm. Crop Breed. Appl. Biot. 2: 141-148.

Irish BM, Goenaga R, Zhang D and Schnell R (2010). Microsatellite fingerprinting of the USDA-ARS Tropical Agriculture Research Station Cacao (Theobroma cacao L.) Germplasm Collection. Crop Sci. 50: 656-667.

Mantel N (1967). The detection of disease clustering and a generalized regression approach. Cancer Res. 27: 209-220.

Oliveira EJ (2006). Desenvolvimento e uso de Marcadores Microssatélites para a Construção e Integração de Mapas Genéticos de Maracujá Amarelo (Passiflora edulis Sims f. flavicarpa Deg). Doctoral thesis, Universidade de São Paulo, Escola Superior de Agricultura Luiz de Queiróz, Piracicaba.

Oliveira EJ, Pádua JG, Zucchi MI and Camargo LEA (2005). Development and characterization of microsatellite markers from the yellow passion fruit (Passiflora edulis f. flavicarpa). Mol. Ecol. Notes 5: 331-333.

Pádua JG (2004). Análises Genéticas de Espécies do Gênero Passiflora L. com Base em Abordagens Filogenéticas, Morfométricas e em Marcadores Microssatélites. Doctoral thesis, Escola Superior de Agricultura Luiz de Queiróz, Piracicaba. 
Pádua JG, Oliveira EJ, Zucchi MI and Oliveira GCX (2005). Isolation and characterization of microsatellite markers from the sweet passion fruit (Passiflora alata Curtis: Passifloraceae). Mol. Ecol. Notes 5: 863-865.

Peñaloza APS and Pozzobon MT (2007). Caracterização Citogenética de Germoplasma Vegetal. In: Recursos Genéticos Vegetais (Nass LL, ed.). Embrapa Recursos Genéticos e Biotecnologia, Brasília.

Primmer CR, Painter JN, Koskinen MT and Palo JU (2005). Factors affecting avian cross-species microsatellite amplification. J. Avian Biol. 36: 348-360.

Rohlf FJ (2000). NTSYS-pc: Numerical Taxonomy and Multivariate Analysis System. Version 2.1. Exeter Software, New York. Rushing F (2003). Tough Plants for Southern Gardens: Low Care, No Care, Tried and True Winners. Cool Springs Press, Nashville.

Santos CAF, Neto FPL, Rodrigues MA and Costa JG (2008). Similaridade genética de acessos de mangueira de diferentes origens geográficas avaliadas por marcadores AFLP. Rev. Bras. Frutic. 30: 736-740.

Silva SDA, Antunes LEC, Anthonisen DG and Lemões JS (2008). Caracterização de genótipos de mirtilo utilizando marcadores moleculares. Rev. Bras. Frutic. 30: 180-184.

Souza MM, Pereira TNS and Vieira MLC (2008). Cytogenetic studies in some species of Passiflora L. (Passifloraceae): a review emphasizing Brazilian species. Braz. Arch. Biol. Technol. 51: 247-258.

Teklu Y, Hammer K and Röder MS (2007). Simple sequence repeats marker polymorphism in emmer wheat (Triticum dicoccon Schrank): analysis of genetic diversity and differentiation. Genet. Resour. Crop Ev. 54: 543-554.

Vaz Patto MC, Satovic Z, Pêgo S and Fevereiro P (2004). Assessing the genetic diversity of Portuguese maize germplasm using microsatellite markers. Euphytica 137: 63-72.

Viana AJC (2009). Delimitação Entre as Espécies Passiflora edulis Sims e Passiflora sp. Nativa da Bahia com Base em Características Citogenéticas, Moleculares e Morfológicas. Master's thesis, Universidade Estadual de Santa Cruz, Ilhéus.

Vitta FA and Bernacci C (2004). A new species of Passiflora in section Tetrastylis (Passifloceae) and two overlooked species of Passiflora from Brazil. Brittonia 56: 89-95.

Wang ML, Barkley NA, Yu JK and Dean RE (2005). Transfer of simple sequence repeat (SSR) markers from major cereal crops to minor grass species for germplasm characterization and evaluation. Plant Genet. Resour. 3: 45-57.

White G and Powell W (1997). Cross-species amplification of SSR loci in the Meliaceae family. Mol. Ecol. 6: 1195-1197. 